\title{
Sosialisasi dan Pemberian Bantuan Handsanitizer Otomatis Sebagai Bagian Pencegahan Dini Bahaya Covid-19 di TPST Sumberberas Muncar
}

\author{
Ikhwanul Qiram ${ }^{\bowtie}$, Adi Pratama Putra ${ }^{2}$, Dewi Sartika ${ }^{3}$, Rezki Nalandari ${ }^{4}$ \\ ${ }^{1,2,3}$ Prodi Teknik Mesin, Universitas PGRI Banyuwangi, Jl. Ikan Tongkol 22, Banyuwangi, 68416 \\ ${ }^{2}$ Prodi Teknik Elektro, Universitas PGRI Banyuwangi, Jl. Ikan Tongkol 22, Banyuwangi, 68416
}

E-mail: ikhwanulqiram@gmail.com ${ }^{1}$

\begin{abstract}
Abstrak - Ancaman penularan Virus Covid-19 salah satunya dipengaruhi oleh perilaku dan lingkungan kurang sehat pada suatu tempat manusia menjalani aktifitas. Seringkali tempat kerja belum cukup disiplin menjalankan protocol kesehatan. Minimnya pengetahuan dan kebiasaan memicu meningkatnya populasi yang rentan untuk tertular atau menularkan. Kegiatan ini bertujuan untuk memberikan sosialisasi tentang bahaya dan pencegahan penularan Covid-19 ditempat kerja. Edukasi yang diberikan meliputi langkah yang diambil atau protokol kesehatan dari pemerintah untuk diterapkan diantaranya, jaga jarak minimal 1 meter antar individu, selalu pakai masker jika beraktifitas di luar rumah, sering mencuci tangan, menggunakan handsanitizer dan lain sebagaianya. Dengan memberikan bantuan hand sanitizer otomatis mampu meminimalisir keborosan terhadap penggunaan cairan handsanitizer.
\end{abstract}

Kata Kunci - Sosialisasi, covid-19, hand sanitizer, tempat kerja

Abstract - One of the threats of transmission of the Covid-19 Virus is influenced by behavior and an unhealthy environment in a place where humans are activity. Often the workplace is not disciplined enough to implement health protocols. The lack of knowledge and habits triggers an increase in the population that is susceptible to infection or transmission. This activity aims to provide socialization about the dangers and prevention of transmission of Covid-19 in the workplace. The education provided includes steps are taken or health protocols from the government to be implemented, including keeping a minimum distance of 1 meter between individuals, always wearing a mask when doing activities outside the home, washing hands frequently, using a hand-sanitizer and so on. By providing automatic hand sanitizer assistance, it can minimize wasteful use of hand-sanitizer fluid.

Keywords - Socialization, covid-19, hand sanitizer, workplace

\section{Pendahuluan}

Badan kesehatan Dunia (WHO) telah menetapkan bahwa Covid-19 sebagai pandemi Global dengan angka kematian (mortality) yang tinggi (Taufik, 2020). Berbagai upaya menghentikan perluasan penyebaran Covid-19 telah dilakukan secara global (Anggia Valerisha, 2020). Hasil penelitian menunjukan bahwa potensi penularan dipengaruhi oleh aspek perilaku yang salah satunya didasari oleh bias kognitif manusia (Buana, 2020). Potensi penularan virus ini dapat dihindari dengan cara menjaga imunitas dan kebersihan diri. Selain itu, penggunaan antiseptik dan desinfektan dapat dilakukan secara efektif (Annisa Lazuardi Larasati, 2020).

Covid-19 tidak hanya berdampak terhadap kondisi kesehatan manusia, namun juga terhadap perekenonomian pada berbagai negara, terutama pada negara berkembang seperti Indonesia. Kondisi ini mampu melumpuhkan berbagai aspek seperti pendidikan dan ekonomi pada skala tingkat lokal, nasional, dan bahkan global (Taufik, 2020)
Sementara itu, kebijakan Pemerintah sebagai langkah antisipasi dampak dari covid-19 turut serta memberikan konsekuensi logis pada aktifitas masyarakat. Imbas yang terjadi adalah berupa perubahan cara dan ritme aktivitas sosial, pelayanan publik maupun kegiatan bisnis seperti menurunya penjualan yang memicu terhentinya operasional perusahaan, ketidaktersediaan pasokan bahan baku dan penurunan permintaan akibat efek panic buying (Yuliana, 2020)

Sebagai langkah pemulihan ekonomi, Pemerintah mencanangkan program "New Normal". Normal Baru merupakan suatu kondisi atau kebiasaan sosial masyarakat atau perilaku individu yang muncul setelah covid-19 selesai (Habibi, 2020). Rekomendasi untuk pencegahan meliputi ktivitas dilakukan harus tetap berpegang pada protokol kesehatan seperti menjaga jarak, memakai masker, menghindari kerumunan, dan kerap mencuci tangan (A.Rosidi, 2020)

Melalui Program Pengabdian Kepada Masyarakat, Tim Fakultas Teknik Universitas PGRI 


\begin{abstract}
Banyuwangi. Sebagai upaya percepatan pemulihan ekonomi, dilakukan kegiatan berupa memberikan sosilaisasi dan pemberian saran penunjang dalam mengindari bahaya penularan Covid-19 di tempat kerja, Salah satu Kelompok masyarakat penerima dukungan kegiatan ini adalah Tempat Pengolahan Sampah Terpadu (TPST) Sumber Beras Muncar Banyuwangi. TPST Sumber Beras Muncar dikelola secara swadaya melalui kepedulian warga yang bernama Bpk. Sudirman. Unit pengolahan sampah ini berdiri sejak tahun 2016 dan setiap harinya mampu mengolah sampah 10-15 Ton/hari. Hasil wawancara pra-kegiatan, unit usaha ini belum menerima bentuk sosialisasi tentang bahaya Covid-19 serta tata cara pencegahannya. Sementara itu terdapat \pm 20 - 25 buruh yang bekerja setiap hari di TPST ini.

Ditengah pandemic melanda, pola aktifitas pekerja di TPST ini tidak ada banyak perubahan dari sebelumnya. Mayoritas pegawai di TPST Sumber Beras Muncar sudah terbiasa menggunakan masker sebagai media untuk menahan aroma sampah yang menyengat. Akan tetapi, selain tingkat kesadaran dan informasi yang terbatas, aktifitas pekerjaan masih belum sepenuhnya menerapkan protokol kesehatan yang ada dan cenderung menganggap remeh penyakit Covid-19. Tentunya potensi penularan Covid-19 yang dihadapi pada pekerja TPST akan semakin besar jika tidak menerapkan pola hidup sehat sesuai anjuran dari pemerintah.
\end{abstract}

\section{SOLUSI DAN LUARAN}

Kegiatan ini merupakan bagian dari bentuk kepedulian dan sumbangsih pengetahuan dari Dosendosen Fakultas Teknik Universitas PGRI Banyuwangi terhadap masyarakat beresiko tinggi di era pandemic. Kegiatan dilaksanakan pada tanggal 15 Oktober 2020 di TPST Sumber Beras Banyuwangi. Kegiatan dihadiri oleh pengelola TPST dan seluruh pekerja yang ada. Adapun langkah dan tindakan solusi yang diterapkan sebagai berikut :

a. Rendahnya pengetahuan dan minimnya informasi tentang bahaya penularan Covid-19 membuat pengelola dan pekerja TPST memiliki tingkat resiko yang cukup rentan untuk tertular atau menularkan. Solusi yang diberikan membangun kesadaran melalui sosialisasi dan edukasi tentang Covid-19 meliputi bahaya dan resiko penularan, gejala klinis saat tertular dan metode pencegahan dini di tempat kerja seperti menjalankan protokol kesehatan dari pemerintah yang telah diterapkan meliputi jaga jarak minimal 1 meter antar individu, selalu pakai masker jika beraktifitas di luar rumah, sering mencuci tangan, menggunakan handsanitizer dan lain sebagainya.

b. Sebagai bentuk media pencegahan bahaya penularan Covid-19 di TPST Sumber Beras
Muncar adalah dengan memberikan Handsanitizer otomatis.
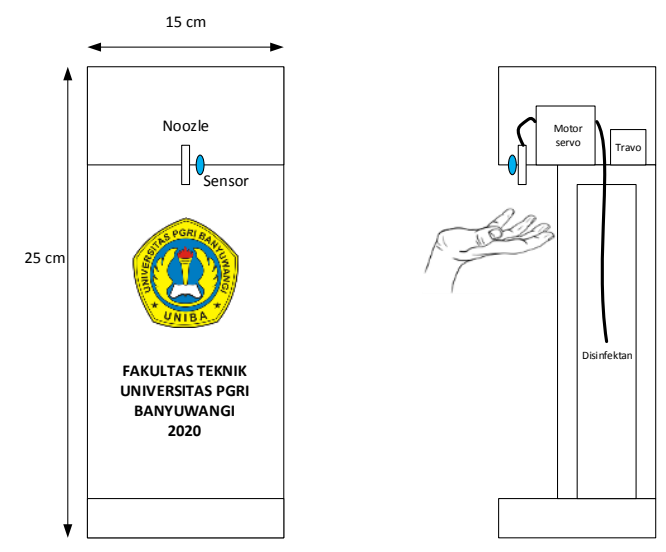

Gambar 1. Desain handsanitizer otomatis

Media ini dibuat oleh team pelaksana kegiatan pengabdian dan diberikan sebagai saran penunjang pencegahan di TPST Sumber Beras Muncar.

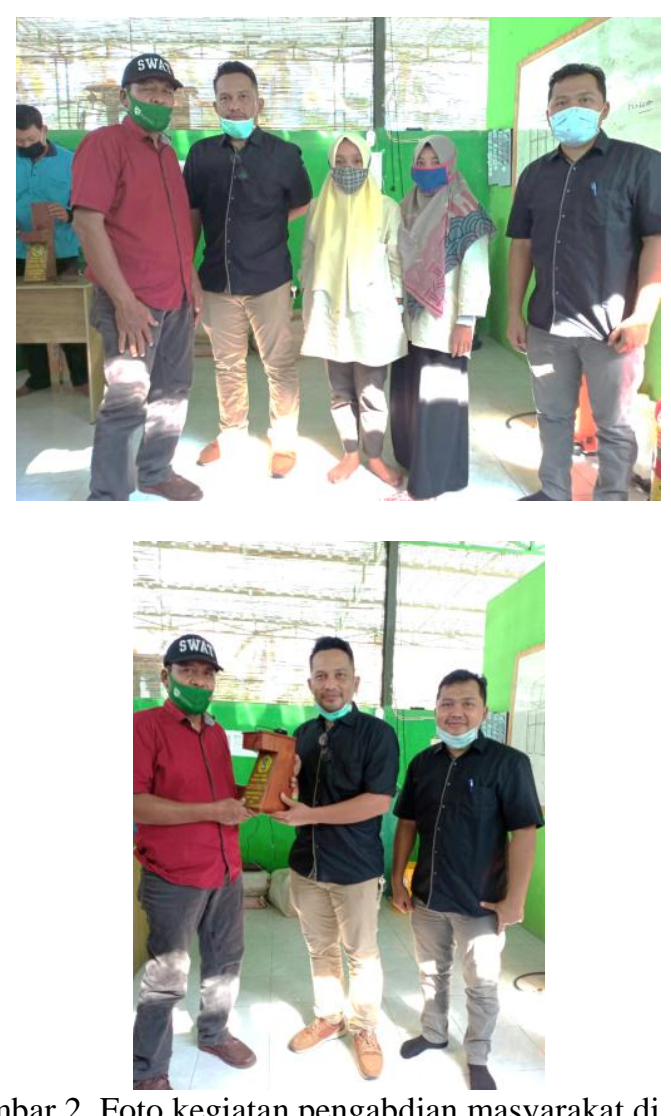

Gambar 2. Foto kegiatan pengabdian masyarakat di TPST Sumber Beras Muncar

\section{KESIMPULAN}

Kegiatan pengabdian ini merupakan bagian dari upaya pencegahan dini penularan covid-19 khususnya 
bagi masyarakat yang bekerja di TPST Sumber Beras Muncar. Melalui kegiatan ini diharapkan akan muncul kesadaran dari pihak pengelola dan pekerja untuk disiplin dalam menjalankan protokol pencegahan yang telah ditetapkan pemerintah. Meski dampak terhadap operasi kerja akan menurun, namun masa usia produktifitas akibat bahaya penularan covid-19 dapat dicegah.

Pemberian peralatan Hand-sanitizer otomatis merupakan salah satu instrumen penunjang yang diharapkan mampu memberikan dampak terhadap pelaksanaan protokol kesehatan kerja yang dijalankan. Dengan energi listrik yang cukup rendah, namun mampu menghindarkan kontak sentuhan tangan secara bergantian antar pekerja.

\section{UCAPAN TERIMA KASIH}

Penulis mengucapkan terimakasih kepada Bapak Sudirman dan segenap perangkat Desa Sumber Beras, Muncar. Berikutnya juga ucapan terimakasih kepada LPPM dan segenap jajaran Fakultas Teknik Universitas PGRI Banyuwangi atas dukungan yang diberikan dalam Program Kemitraan bagi Masyarakat tahun 2020 ini.

\section{DAFTAR PUSTAKA}

A.Rosidi, 2020. Penerapan New Normal (Kenormalan Baru) Dalam Penanganan Covid-19 Sebagai Pandemi Dalam Hukum Positif. Journal Ilmiah Rinjani, 8(2).

Anggia Valerisha, M. A. P., 2020. Pandemi Global COVID-19 dan Problematika Negara-Bangsa: Transparansi Data Sebagai Vaksin Socio-digital?. $J I H I$, Issue Edisi Khusus.

Annisa Lazuardi Larasati, C. H., 2020. Penggunaan Desinfektan dan Antiseptik pada Pencegahan Penularan Covid-19 di Masyaraka. Majalah Farmasetika, 5(3), pp. 137-145.

Buana, D. R., 2020. Analisis Perilaku Masyarakat Indonesia dalam Menghadapi Pandemi Virus Corona (Covid-19) dan Kiat Menjaga Kesejahteraan Jiwa. SALAM: Jurnal Sosial dan Budaya Syar-i, 7(3), pp. 217-226.

Habibi, A., 2020. Normal Baru Pasca Covid-19. ADALAH, 4(1).

Taufik, E. A., 2020. The Impact of Covid-19 Pandemic on Business and Online Platform Existance. Jurnal Pengembangan Wiraswasta, April.22(1).

Yuliana, L., 2020. Dampak Kondisi Pandemi Di Indonesia Terhadap Trend Penjualan (Studi Kasus Pada Pd. Sumber Jaya Aluminium). Jurnal Riset Bisnis, Oktober, 4(1), p. $27-38$. 